\title{
Improving the efficiency of early table beet cultivation in the North-West region of Russia
}

\author{
Nikolay Romanovskiy ${ }^{1}$, Aleksandr Sergeyev ${ }^{1}$, Eduard Papushin ${ }^{1, *}$, Ivan Irkov $^{2}$, and Alexey \\ Bykov $^{3}$ \\ ${ }^{1}$ Federal State Budgetary Scientific Institution "Federal Scientific Agroengineering Center VIM", \\ 196625, branch in 3, Filtrovskoje Shosse p.o. Tiarlevo, RU, Saint Petersburg, Russia \\ ${ }^{2}$ Federal State Budgetary Scientific Institution "Federal Scientific Vegetable Center", 143072, branch \\ in 14, Selektsionnaya st., Odintsovo, village VNIISSOK, RU, Moscow region, Russia \\ ${ }^{3}$ Privat Farm Bykov Alexey Dmitrievich, Leningrad region, Kirovsky district, municipal settlement \\ Priladozhskiy, Russia
}

\begin{abstract}
The appearance of the first marketable root crops with a diameter of more than $50 \mathrm{~mm}$, categorized as elite, in the North-West region of the Russian Federation, may already occur by the end of the third decade of June. The crop price during this period is at least twice the one during mass harvesting. The price depends on the product's presence on the consumer's market as well as on weather conditions in the regions of traditional suppliers. In some years, the price can differ by a factor of 3-4. By the time of mass harvesting using traditional technology, the number of elite root crops does not exceed $50 \%$. In order to assess the effectiveness of the proposed early beets cultivation technology, the studies were carried out in the economic conditions of the farm, Leningrad region on the area of 3 hectares. According to the research results, the proposed technology allows to reach 3.3-fold increase of the root crops yield, which are to be sold fresh through the retail network, compared to the traditional one. The gross income using the proposed technology, calculated for sales prices of 2019 , amounted to 384.6 thousand $\mathrm{rub} /$ ha against 125.2 thousand $\mathrm{rub} / \mathrm{ha}$ using traditional cultivation techniques.
\end{abstract}

\section{Introduction}

Healthy diet is one of the crucial factors that have an effect on human life span by providing the body with the essential minerals, vitamins and microelements [1-3].

Fresh vegetables are the main suppliers of the required substances. Table root crops (carrots and table beets) make up $38.0 \%$ of the total amount of vegetables. Early varieties and hybrids of table beet have a growing season of at least 95-100 days. However, due to the different energy of seed germination, uneven soil fertility, proximity of groundwater and other factors, the accumulation of the biological mass of root crops is not uniform.

\footnotetext{
${ }^{*}$ Corresponding author: papushin@sznii.ru
} 
The developed science-based standard of the agricultural production consumption per capita determines the range and amount of each type of product. The largest amount of vital substances is found in vegetables. Among the crop products, the share of table roots (carrot, table beetroot) is $38.0 \%$ of the total weight. It is necessary not only to offer a wide range of products but also to provide fresh product on the consumer market for a longer period of the year $[4,5]$. In this regard, most farms produce early vegetables, which also provides farms with cash flow in the summer. Early vegetable prices vary considerably depending on the timing of its sale, and may be 3-5 times higher in the initial period [5].

The pricing of the early vegetables depends on its availability on the consumer's market, which, in turn, depends on weather conditions in the production regions. In the North-West region the earliest products include mainly all kinds of cabbage, since it has a broad range of varieties and hybrids with different vegetation period, ultraearly-ripening hybrids have a growing period of 55 days [6]. There are some table carrot hybrids with a growing season of 55 days. In the Leningrad region, the sale of vegetables with such growing period is already possible in the third decade of June.

Early table beetroot hybrids have a growing period of at least 85 days, so the early beets demand is satisfied by supplies from the southern regions of the country.

The goal of this work is to determine the agrotechnical indicators of crops during the harvest of early production and assessment of the economical effectiveness of the proposed technology.

\section{Materials and methods}

For the conditions of the North-West region of the Russian Federation, together with the farm "Bykov A.D.", a versatile technology of growing table beet providing for obtaining of early yield was developed. The key technology differences are sowing the seeds of early multisprout hybrids followed by selective harvesting of root crops as they reach marketable condition. This technology has been tested on the farm "Bykov A.D.", located in the Kirovsky district of Leningrad region on the area of 3 hectares.

When cultivating table beets using this technology, the field choice is of great importance. The most favorable ones are fields with light to medium loam that has large moisture capacity. Sowing is performed on the ridge surface [7-9]. During the growing season, mechanical weeding of row spacings is carried out; if necessary, the zone of plants is weeded manually.

Due to the different energy of seed germination, uneven soil fertility, as well as the proximity of groundwater, the development and growth of the mass of root crops is not uniform. When root crops reach commercial suitability, their selective harvesting is performed [10-13].

In the North-West region, with early sowing, beetroot reaches the elite category in late June and early July. The frequency of selective harvesting depends on weather conditions and the demand for beets in the market, usually 3-5 days.

The selective harvesting technology was carried out as follows. Workers sample root crops as they reach marketable condition, collect them in a heap, and then perform the separation of foliage and load crops in containers. Filled containers are loaded on a transport trailer, moving between the rows, and transported to the transfer or temporary storage point. At the end of the harvesting of early crops, a complete harvesting of root crops is carried out.

The technology trial was performed on the fields of the farm "Bykov A.D." The soil on the site is medium loamy. Beet variety is a hybrid Wodan $F_{1}$, multisprout. Sowing two-line with a distance between the lines of $5 \mathrm{~cm}$, was carried out on May 10, 2019, on the ridge 
surface with a row spacing of $75 \mathrm{~cm}$. The sowing rate of seeds is $250-350$ thousand pcs/ha. Planting depth is $2-3 \mathrm{~cm}$, followed by soil compaction.

The data necessary to determine the economic efficiency of the technology, which are the yield, the volume of one-time harvest, the selling price and the dynamics of its change, are determined according to the farm data. During harvesting, the root crops are assessed for compliance with the Russian GOST 32285-2013 requirements for the diameter of the root crop (determined by the average size and its variance). For this, the collected root crops are measured in an amount of at least 100 pieces. The average weight of a root crop is found by weighing the root crops in a container and then dividing it by their number.

Before the start of selective harvesting, the number of plants per hectare is determined. For this purpose, three plots 3 meters long each, arranged diagonally and equidistant lengthwise, counts the number of plants. The average of three replicates is used to determine the number of plants $(N)$ by the expression:

$$
N=\frac{10^{4} \cdot n}{a \cdot l}, \mathrm{pcs} / \mathrm{ha},
$$

where $n$ is the average number of root crops on the accounting plot, pcs;

$a$ is row spacing, $\mathrm{m}$;

$l$ is plot length, $\mathrm{m}$

The productivity of workers during selective harvesting was determined by the number of container units filled per unit of time.

To determine the average productivity of workers in the collection of beets, the shift time and the number of workers employed in harvesting were determined. At the end of the shift, the number of filled containers was counted, this number was divided by the number of workers involved in harvesting. The productivity was expressed as number of filled packaging units per shift per person. Hourly productivity was determined accordingly by division by shift time.

For productivity in units of weight, the average weight of the filled container was determined. For this, at least five filled containers were weighed; the results obtained were used to determine the average weight of the product per container.

The productivity of workers was determined along with determining the yield a single harvest:

$$
\Pi=\frac{\Pi_{T} \cdot m_{T}}{n_{p} \cdot t_{x}}, \mathrm{~kg} / \mathrm{h},
$$

where $\Pi$ is productivity, $\mathrm{kg} \cdot$ person / $\mathrm{h}$;

$\Pi_{\mathrm{T}}$ is the number of containers filled during timekeeping;

$\mathrm{m}_{\mathrm{T}}$ is the beets mass in containers, $\mathrm{kg}$;

$\mathrm{n}_{\mathrm{p}}$ is the number of workers on harvesting;

$\mathrm{t}_{\mathrm{x}}$ is the timekeeping length, hours;

Similar indicators were determined on sowing table beets before mass harvesting. For this, a part of the overall crop was not selectively harvested.

Before mass harvesting on the control plot, an agricultural assessment of the state of beet was carried out with the determination of the number of plants per hectare (dimensional characteristics of root crops, their standard compliance), and the productivity of workers during harvesting was determined too. 
The yield of standard root crops is determined as the sum of the yields of one-time harvests and the yield of mass harvesting by the expression:

$$
y=\sum_{i=1}^{i} y_{P}+Y_{M} \cdot R_{S}, \mathrm{t} / \text { ha }
$$

where $\mathrm{Y}_{\mathrm{P}}$ is the yield of a single harvest, $\mathrm{t} / \mathrm{ha}$;

$Y_{M}$ is the yield of mass harvesting, $\mathrm{t} / \mathrm{ha}$;

$R_{S}$ is the standard compliance of root crops, $\%$.

Using the results obtained, the gross income was determined for both the researched and basic technologies by the expression:

$$
D=\sum_{i=1}^{i}\left(10^{3} Y_{P}^{i} \cdot L_{P}^{i}-\frac{10^{3} \cdot Y_{P} \cdot O_{T}-Y_{P}^{i} \cdot O_{\Pi P}}{m_{T}}\right)+\frac{10^{3} \cdot Y_{M} \cdot O_{T}}{m_{T}}, \text { rub./ha; }
$$

where $\bigsqcup_{p}^{i}$ is the selling price for beets on the ith harvest, rub/kg;

$O_{T}$ is the payment for products collected in containers, rubles;

$O_{\Pi P}$ is the payment for loading and unloading, rubles/t.

Harvesting costs include the costs of performing basic operations (picking root crops, loading and unloading operations performed when collecting products and unloading them at the points of sale or storage).

Labor costs for harvesting is the sum of labor costs while harvesting root crops at a single harvest:

$$
3_{T P}=\sum \frac{y_{P} \cdot 10^{3}}{m_{T} \cdot \Pi}, \text { person } \cdot \mathrm{h} / \mathrm{ha}
$$

where $m_{T}$ is the mass of root crops in a container, $\mathrm{kg}$;

$\Pi$ is productivity, $\mathrm{kg} \cdot$ person $/ \mathrm{h}$.

Comparing the indicators obtained per technology, the effectivity of the compared technologies was determined.

Based on the results obtained, the indicators of technological labor costs and economic efficiency were determined.

\section{Results}

The highest selling price for table beets of the elite category corresponding to Russian GOST 32285-2013 in the initial period of sale. Figure 1 shows the graphs of selling price of early beets for the period of 2017-2019 years. 


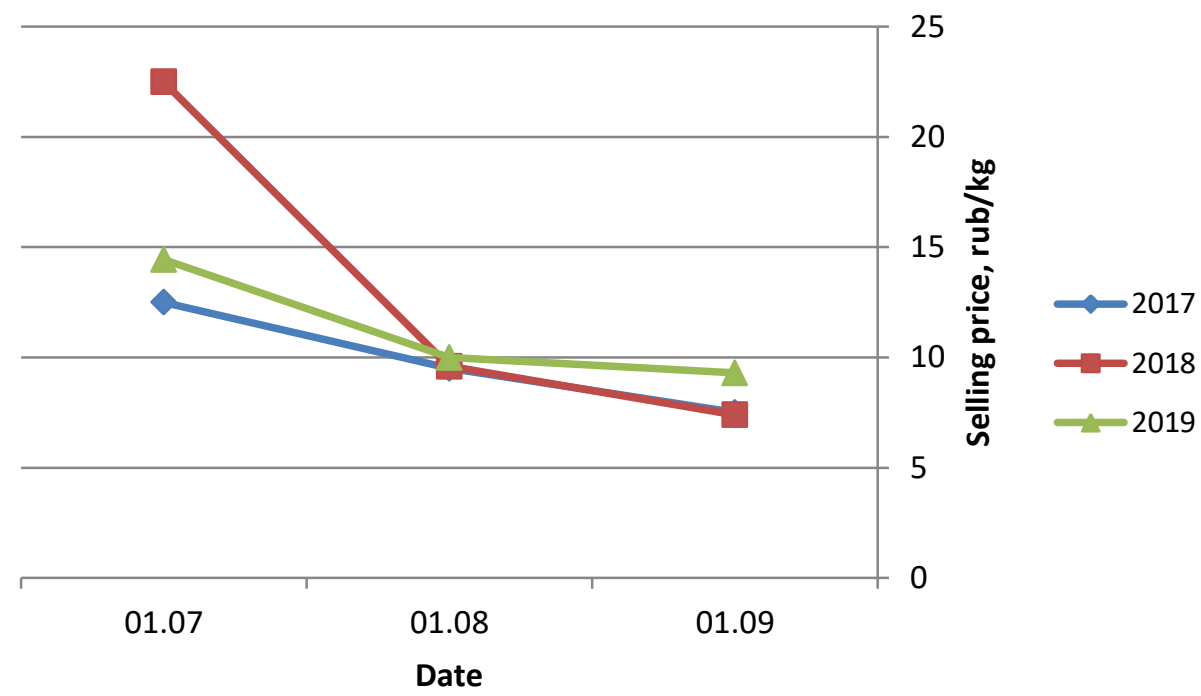

Fig. 1. Change in the selling price of early beets for the period of 2017-2019

As can be seen from the graph, the initial selling price for year 2019 is 2.7 times higher than for 2017. The selling price depends mainly on the availability of beetroot in the consumer market, which, in turn, depends on weather conditions in the territory of potential suppliers. It should be noted that in the initial period the price is higher by a factor of 1.5 1.7. Analysis of changes in selling prices of table beets for 2017 and 2019 years led to the conclusion about the necessity to change the harvesting and selling strategies and to implement them in the early beet cultivation technology. As a result of processing data on sales prices for year 2019 (Fig. 2), a mathematical model was obtained in the form of a regression equation (6) reflecting the price change depending on the predicted sales time. 


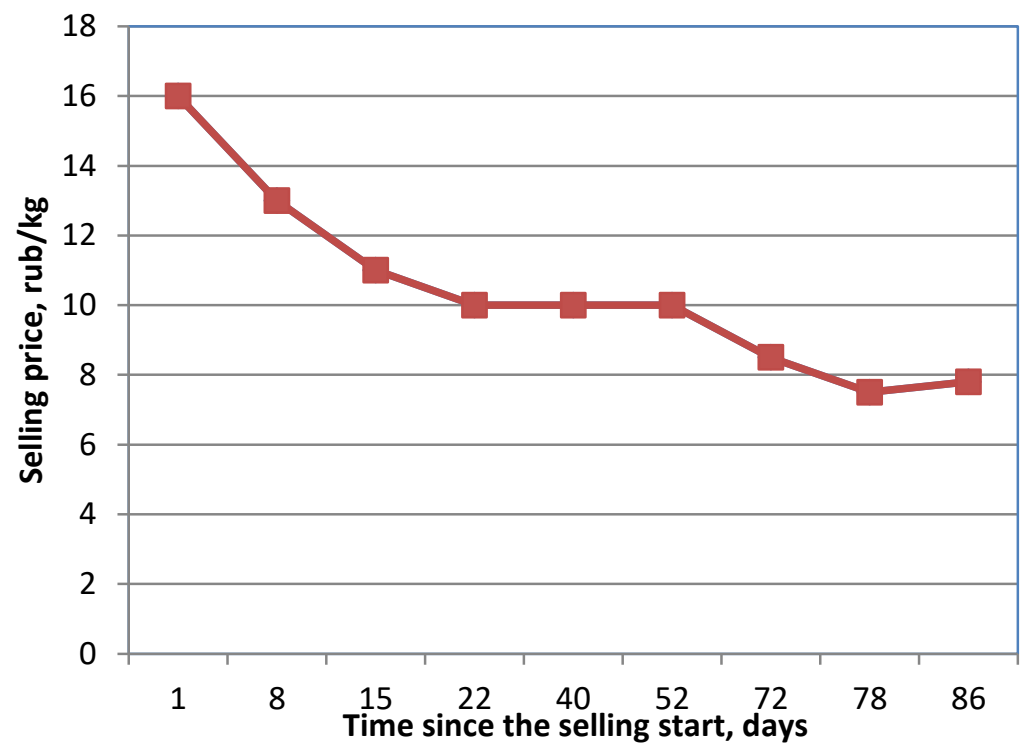

Fig. 2. Change in selling price of early beets in 2019

For the purposes of building it, it was assumed that the selling begins from the end of the third decade of June. This model allows you to adjust, if necessary, the strategy for the sale of marketable products.

$$
Ц p=14.6134-0.172806 \cdot T+0.0011377 \cdot T^{2} \quad R^{2}=85
$$

where $\zeta_{p}$ is the selling price of beets, rubles $/ \mathrm{kg}$; T is the time since the selling start, days; $R^{2}$ is the determination coefficient.

Fig. 3 shows a graph of changes in the yield of a one-time harvest of early crops based on research results in 2019. 


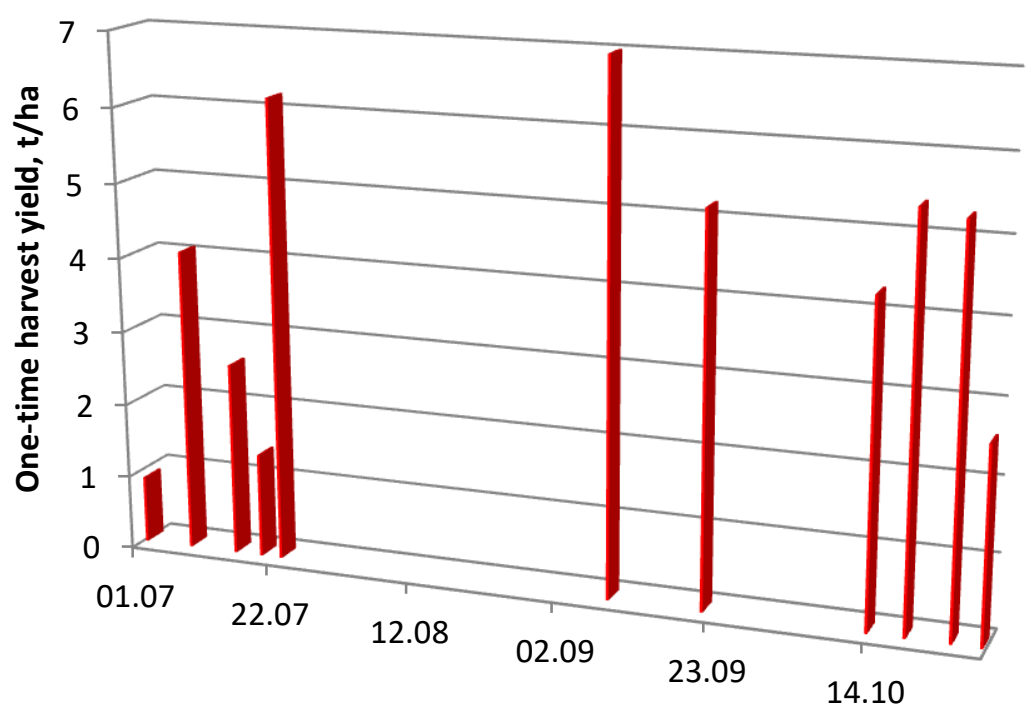

One-time harvest date

Fig. 3. Changing yields of a one-time harvest of early crops based on research results in 2019

The yield of a single harvest in the initial period of harvesting depends on the number of root crops that have reached marketability (Fig. 4). After that, the yield of a single harvest was determined by market needs. Root crops were collected as necessary.

Fig. 4 shows a graph of changes in income earned by selective harvesting of beetroot depending on the date of a one-time harvest in 2019.

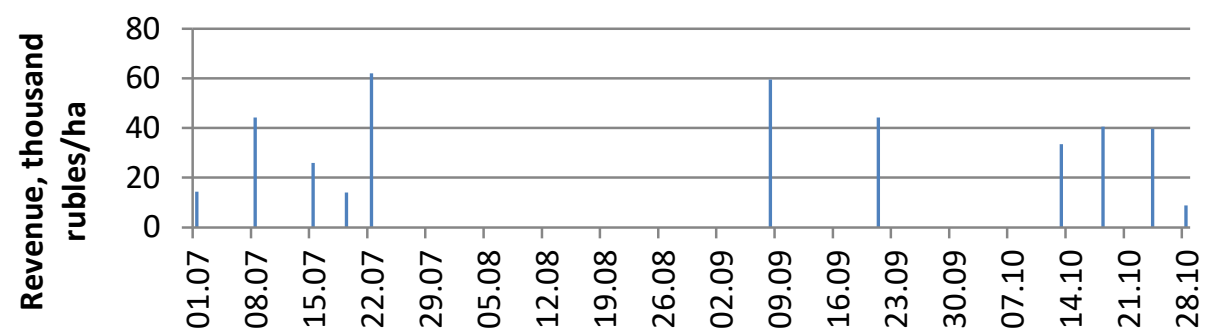

Time since the selling start, days

Fig. 4. Change in the income received for selective harvesting of table beets from the date of the onetime harvest in 2019.

Table 1 shows the dimensional properties of selectively harvested root crops and sowing condition at different periods

Table 1. Dimensional properties of table beet root crops and condition of sowing with selective harvesting

\begin{tabular}{|c|c|c|c|}
\hline Date of selective harvest & \multicolumn{2}{|c|}{ Root crop properties } & \multirow{2}{*}{$\begin{array}{c}\text { Number of plants, } \\
\text { thousand pcs/ha }\end{array}$} \\
\cline { 2 - 3 } & $\begin{array}{c}\text { Root crop average } \\
\text { diameter, } \mathbf{~ m m}\end{array}$ & $\begin{array}{c}\text { Root crop diameter } \\
\text { dispersion, } \mathbf{~ m m}^{\mathbf{2}}\end{array}$ & \\
\hline 1.07 & 56.3 & 3.4 & 360.0 \\
\hline
\end{tabular}




\begin{tabular}{|c|c|c|c|}
\hline 9.07 & 63.7 & 6.4 & 341.0 \\
\hline 22.07 & 64.7 & 7.85 & 281.0 \\
\hline 21.08 & 66.6 & 7.8 & 221.0 \\
\hline 13.09 & 81.7 & 6.15 & 183.0 \\
\hline 24.09 & 83.3 & 7.05 & 126.0 \\
\hline
\end{tabular}

By analyzing the results, it can be noted that as the interval between harvesting grows, the average weight of harvested root crops increases. The study of the yield in the control plot showed that the total yield was 34.5 t/ha, while $13 \%$ of the root crops were nonstandard in size (less than $50 \mathrm{~mm}$ ) and appearance. Elite root crops accounted for $47 \%$ of the total weight of harvested root crops. The rest, standard-conforming, accounted for $40 \%$. The selling price at the time of harvest was $8.1 \mathrm{rub} / \mathrm{kg}$ for elite and $4.0 \mathrm{rub} / \mathrm{kg}$ for standard, respectively.

With complete harvest of the plot the yield was $2.8 \mathrm{t} / \mathrm{ha}, 1.6 \mathrm{t} / \mathrm{ha}$ being elite. The calculation of the total yield showed that using the proposed technology the yield of elite root crops is $44.98 \mathrm{t} / \mathrm{ha}$ versus $13.5 \mathrm{t} / \mathrm{ha}$ with traditional technology. Gross income using the proposed technology, calculated on the prices of 2019, amounted to 384.6 thousand rub/ha against 125.2 thousand $\mathrm{rub} / \mathrm{ha}$ or 3.06 times higher. The labor costs by technology amounted to: the proposed -13.7 person $\mathrm{h} / \mathrm{t}$, traditional 9.5 person $\mathrm{h} / \mathrm{t}$

\section{Discussion}

The goal of this work was to determine the agrotechnical indicators of crops during the harvesting of early table beetroot and to assess the economic efficiency of the proposed technology.

The enhancement of vegetable manufacturing technology is directed mainly on yield increasing [13-15]. It should be noted that with the advent of the market economy, obtaining the maximum profit with a reduction in the required areas occupied by each crop takes the first place, which ensures savings in consumables - fertilizers, seeds, pesticides; labor costs per unit of product obtained.

When cultivating table beets using traditional technology, the elite root crops fraction of the total mass does not exceed $50 \%$, depending on weather conditions. When harvesting by hand, the collection of standard root crops is not efficient and there is a high probability that the crop remains unharvested under the snow [9-10]. According to our data, depending on weather, soil and other conditions, the fraction of standard vegetable production ranges from $50 \%$ to $80 \%$, depending on the specific year.

We have put forward a hypothesis about the effectiveness of selective harvesting of table beets, since it is an unevenly ripening crop. Thinning it by harvesting root crops that have reached marketable size will be effective both to increase yields and to increase the economic efficiency of production.

The results obtained have shown the economic efficiency of selective harvesting of root crops. Improving the production efficiency of early beetroot is possible with an increase in gross income from its sale, taking into account the cost of harvesting.

The next stage of research is the formation of technical and economic requirements for technical means for the mechanization of the selective harvesting process.

\section{Conclusions}

1. The research findings of agrotechnical indicators of crops and dimensional properties of root crops lead to the conclusion that the beginning of selective harvesting in the conditions of North-West region of the Russian Federation can be started in the first decades of July. 
2. The use of the proposed technology makes it possible to increase the yield of products corresponding to the size of the category "elite" up to $95 \%$, against $39 \%$ when cultivated by traditional technology.

3. Using the proposed technology of growing early table beet provides increased yield of commercial varieties (elite and ordinary) by a factor of 3.3 and increases the table root crops cultivation efficiency by a factor of 3.06 .

\section{References}

1. T. Clifford, G. Howatson, D. J. West, E. J. Stevenson, The potential benefits of red beetroot supplementation in health and disease (Open access) Nutrients, 7(4), 28012822 (2015)

2. B. Guldiken, G. Toydemir, K. Nur Memis, S. Okur, D. Boyacioglu, E. Capanoglu, Home-Processed Red Beetroot (Beta vulgaris L.) Products: Changes in Antioxidant Properties and Bioaccessibility. International Journal of Molecular Sciences, 17, 858 (2016) https://doi.org/10.3390/ijms17060858

3. Z. Niziol-Lukaszewska, M. M. Gawęda, Influence of cultivar on the content of selected minerals in red beet roots (Beta vulgaris L.) FoliaHorticulturae, 28(2), 143-150 (2016) $\mathrm{http} / / / \mathrm{www}$.degruyter.com/view/j/fhort (Last accessed 12.05.2020) doi : 10.1515/fhort2016-0017.

4. S. A. Vetrova, V. A. Zayachkovskyi, S. M. Sirota, Monogerm table beet from the perspective of economic efficiency, IOP Conference Series: Earth and Environmental Science, Volume 395, International Conference on Sustainable Development of CrossBorder Regions (2019) doi: 10.1088/1755-1315/395/1/012052

5. K. Trimpler, N. Stockfisch, B. Märländer, Efficiency in sugar beet cultivation related to field history, European Journal of Agronomy, 91, 1-9 (2017) doi: 10.1016/j.eja.2017.08.007

6. N. Aouadi, J. N. Auberoto, J. Caneill, N. Munier-Jolain, Analyzing the impact oft he farming context and environmental factors on cropping systems: a regional case study in Burgundy. Eur. J. Agron, 66, 21-29 (2015) doi: 10.1016/j.eja.2015.02.006.

7. T. L. Factor, L. F. V. Purquerio, J. M. de C. Silveira, S. Lima, A. H. Calori, Yield and quality of table beet in function of plant establishment method and production system, Acta Hortic. 1249, 37-42 (2019) doi:10.17660/ActaHortic.2019.1249.7

8. L. B. Carvalho, C. D. Guzzo, R. A. Pitelli, A. B. C. Filho, S. Bianco, The effects of the coexistence of weed communities on table beet yield during early crop development, Acta Scientiarum. Agronomy Maringá, 32(4), 709-714 (2010) doi: 10.4025/actasciagron.v32i4.4649

9. J. Wießner, N. Stockfisch, B. Märländer, Approach for determining the eco-efficiency of sugar beet cultivation in Germany, journal für kulturpflanzen, 62(11), 409-418 (2010) doi: 10.5073/JfK.2010.11.03

10. A. M. Gaharwar, J. D. Ughade, Effect of plant spacing on marketable yield of table beet (Beta vulgaris L.). Internat. Res. J. Agric. Eco., Stat., 8(1), 51-55 (2017) doi:10.15740/HAS/IRJAES/8.1/51-55.

11. M. Takács-Hájos, T. Rubóczki, Effects of environmental factors on morphological and quality parameters of table beet root. International Journal of Horticultural Science, 18 (2), 139-146 (2012)

12. B. Hanse, G. D. Vermeulen, F. Tijink, H.-J. Koch, B. Märländer, Analysis of soil characteristics, soil management and sugar yield on top and averagely managed farms 
growing sugar beet (Beta vulgaris L.) in the Netherlands. Soil Tillage Res. 117, 61-68 (2011) doi: 10.1016/j.still.2011.08.008.

13. T. Garnett, M.C.Appleby, A. Balmford, I.J.Bateman, T.G.Benton, P.Bloomer,

14. B. Burlingame, M. Dawkins, L. Dolan, D.Fraser, M. Herrero, I. Hoffmann, Smith P., T. P. K. Hornton, C. Toulmin, S. J. Vermeulen, H. C. J. Godfray, Sustainable intensification in agriculture: premises and policies. Science, 341, 33-34 (2013) doi: $10.1126 /$ science. 1234485

15. S. Enchev, E. Dimcheva, T. Kikindonov, Dynamics of biomass accumulation in sugar beet, fodder beet and table beet. Journal of Mountain Agriculture on the Balkans, 21(3), 162-171 (2018)

16. S. Enchev, T. Kikindonov, E. Dimcheva, Influence of the Sowing Rate, Fertilization and the Date of Harvesting on the Productivity of Table Beet, 23, 118-125 (2020) 